\title{
МАРИНІСТИЧНА ЛІРИКА ЯК ХУДОЖНІЙ ФЕНОМЕН РОСІЙСЬКОГО РОМАНТИЗМУ (НА МАТЕРІАЛІ ТВОРЧОСТІ В. А. ЖУКОВСЬКОГО ТА М. Ю. ЛЕРМОНТОВА)
}

\author{
Карпіна О. С.
}

\section{ВСТУП}

Тема моря - одна з найдавніших у світовій літературі, адже море завжди вважалося частиною людського життя. Його велич зображалася художниками слова в усі часи досить широко, але найбільш специфічне розкриття теми моря як програмної відбулося саме в романтизмі. Свобода для романтичного героя - найвища цінність, а єднання з природою - найкращий спосіб іiї знаходження. Саме тому особливе значення у творах романтиків набуває зображення морської стихії, у якій вони бачать притулок вільного духу вічних мандрівників. Таким чином, очевидним $є$ той факт, що образ моря посідає важливе місце в естетиці романтизму та $€$ невід'ємною частиною художнього світу романтичних творів.

Цілком закономірно, що саме в епоху романтизму виникає такий яскравий художній феномен, як мариністична література. Поняття «мариністика» (від лат. marinus - морський) асоціюється в багатьох людей передусім із живописом. Це можна пояснити тим, що романтизм як світосприйняття охопив різноманітні галузі культури - літературу, музику, живопис, театр. Він подарував світові прекрасні імена, які назавжди прославили свою епоху: Дж.Г. Байрон, Г. Гейне, Ф. Ліст, Р. Вагнер, Е. Делакруа, І.К. Айвазовський та ін. Це був час, за словами Ф.В. Шлегеля, «буяння людського духу» ${ }^{1}$, який відчув себе, як ніколи розкутим у своїх почуттях і бажаннях. У більш широкому сенсі під «мариністикою» варто розуміти напрями різних видів мистецтва, присвячені морській тематиці.

Серед американських романтиків XIX ст., які зверталися до теми моря, особливо виділяється Дж.Ф. Купер. Саме він уважається родоначальником жанру морського роману, що має свої специфічні особливості. Гідне розкриття морської теми мало місце й у романтичній поезії. Поети-романтики надавали великого значення зображенню моря в його спокійній нескінченності й водночас

1 Ніколенко О.М. Романтизм у поезії. Г. Гейне, Дж.Г. Байрон, А. Міцкевич, Г. Лонгфелло : посібник для вчителя. Харків : Ранок, 2003. С. 6. 
у могутній і небезпечній величі. Першовідкривачем і найвпливовішим у сфері мариністичної лірики був англійський поет Дж.Г. Байрон. Варто зазначити, що море прославляли у віршах поети різних національностей, серед яких особливе місце займають Г. Гейне, А. Міцкевич, Ш. Петефі, А. де Ламартін, В. Гюго.

До образу моря неодноразово зверталися й російські поетиромантики XIX ст.: В.А. Жуковський, О.С. Пушкін, М.Ю. Лермонтов, К.М. Батюшков, С.А. Баратинський, Ф.І. Тютчев, О.І. Полежаєв та ін. Незважаючи на те що їхня багатогранна творчість вивчається літературознавцями вже третє століття, вона висуває немало загадок та окремі ï аспекти досі є недослідженими. Одним із таких аспектів творчої спадщини поетів $\epsilon$ аналіз морської теми та іiі художньої реалізації в їхній романтичній ліриці, який актуалізується в контексті сучасних досліджень у сфері літературної мариністики.

Як відомо, характерною особливістю романтизму як естетичної системи є використання символіки, тому образ моря символізується, утілюючи душевний стан романтичного героя - бунтівника, який протиставляє себе навколишньому світу й кидає йому виклик. Цей символ у мистецтві романтизму багатозначний. Найчастіше море у творах романтиків $є$ уособленням стихії свободи та образом динамічного початку. У поезії романтизму море $\epsilon$ синонімом безконечності, часу й навіть вічності. Бурхливе та непокірне, воно нагадує людське життя 3 його численними проблемами та перешкодами. Для одних романтичних героїв море - райський шлях, що веде в прекрасні екзотичні країни та рятує від світу філістерів, тоді як для інших - постійне нагадування про необхідність повернення на батьківщину. Правильне тлумачення достатньо багатогранної символіки моря є важливим ключем до розуміння концепції світу та людини в романтичній літературі.

Вагоме значення в контексті розвідки має введення видатним російським філологом В.М. Топоровим поняття «поетичного» комплексу моря, до якого входять, окрім самого моря, хвилі, берег, морське дно та небо. Кожний із зазначених мотивів «морського комплексу» набуває в романтичній ліриці свого символічного значення.

Чітким $\epsilon$ розрізнення вченим «реального» моря та моря, яке «заміщає» інші образи. Опис «реального» моря «природний» та «об'єктивний». «В этой романтической версии «морского комплекса» речь идёт, действительно, о море как объекте изображения, о его свойствах «объективного» характера - огромное, беспредельное, могучее, бурное, вольное, свободолюбивое и т.п. Все эти свойства 
моря, как и само оно, зримы, элементарно ощущаемы»². Коли море «заміщає» той чи інший образ, воно слугує лише формою опису, своєрідною глибинною метафорою та являє собою «морський» код «неморського» повідомлення. Отже, описується щось ширше та глибше, ніж просто море. Найчастіше море «заміщає» образ людини, зокрема самого поета, який немов поміщається в рамку між морем внизу та небом угорі. Зазначені вище два типи «морських» описів включені в принципово різні контексти, і кожний із них переслідує свої цілі, які можуть неповністю усвідомлюватися навіть самим автором опису або усвідомлюватися помилково.

Розглянемо реалізацію «поетичного» комплексу моря в ліриці двох видатних представників російського романтизму - В.А. Жуковського та М.Ю. Лермонтова.

\section{1. Аналіз «морського комплексу» \\ в романтичній ліриці В.А. Жуковського}

3 іменем В.А. Жуковського пов’язана важлива епоха в російській поезії початку XIX ст. Поет, який виступав у перші роки 3 карамзинських позицій, уважається засновником російського романтизму, який був досить оригінальним явищем, що виросло на своєму національному корінні. В.Г. Бєлінський назвав його «литературным Колумбом Руси», який відкрив їй «Америку романтизма» ${ }^{3}$.

В.А. Жуковський - один із творців нової російської поезії. Він був першим російським поетом, який надав ліриці широкі, рухливі межі, здатні вміщувати духовний досвід людини нового часу. Сильний і благотворний вплив поезії В.А. Жуковського на російську літературу усвідомили вже його сучасники. О.С. Пушкін, який уважав себе його учнем, писав: «Жуковский имел решительное влияние на дух нашей словесности!..».

Поезія В.А. Жуковського пройнята смутком і журбою, за якими відчувається глибока незадоволеність сучасною йому дійсністю, де гинуть надії та панує користь, де в пошані чини та гроші, а високі моральні ідеали втрачають своє значення. Упевненість у неможливості звичайного земного щастя й водночас бажання знайти гармонію зі світом - постійні мотиви лірики поета, які багато в чому зумовили характер його творчості.

2 Топоров В.Н. Миф. Ритуал. Символ. Образ: исследования в области мифопоэтического: избранное. Москва : Издательская группа «Прогресс» «Культура», 1995. С. 578.

3 Жуковский В.А. Избранные произведения : стихотворения, баллады, повесть в стихах : для ст. школ. возраста / сост., предисл., примеч. и словарь В.И. Коровина; худож. С.Г. Якутович. Киев : Веселка, 1984. С. 5.

${ }^{4}$ Там само. С. 21. 
Оскільки поет упевнений у недосконалості світу, у якому неможливим $\epsilon$ щастя, він прагне до пошуку романтичного ідеалу, яким стає для нього світ природи. В.А. Жуковський виступив як перший творець ліричного пейзажу в російській літературі й указав у цьому дорогу іншим поетам.

Велика роль у романтичній ліриці В.А. Жуковського відводиться типовому для романтизму образу моря, яке сприймається поетом набагато ширше, ніж просто фон, на якому розгортається лірична ситуація вірша.

У мариністичній ліриці В.А. Жуковського можна виділити низку досить глибоких за змістом віршів, аналіз яких допоможе зрозуміти особливості сприйняття образу моря поетом. Одним із таких віршів $\epsilon$ написана в 1816 р. «Пісня», яка являє собою вільний переклад німецької народної пісні. Ліричний герой звинувачує себе в тому, що не зміг зберегти каблучку, дану йому «душой-девицей», упустивши іiі в море та порушивши тим самим обіцянку завжди ії носити: «Кольцо души-девицы / Я в море уронил; / С моим кольцом я счастье / Земное погубил» ${ }^{5}$. Герой намагається знайти каблучку за допомогою невода, а потім прохає «ветер полуночный» дістати іiі 3 морського дна. Але море $є$ нещадним: воно виявляється сильнішим і за земну стихію, і за повітряну внаслідок своїх безмежних просторів і наповнює душу безсилої порівняно з ним людини відчаєм: «Кольцо юркнуло в воду; / Искал... Но где искать!..» ${ }^{6}$. Мотив морського дна, що поглинуло каблучку, виникає не випадково: він символізує втрачене кохання: «С тех пор мы как чужие! / Приду к ней - не глядит! / C тех пор моё веселье / На дне морском лежит!» ${ }^{7}$. Каблучка дорожча герою за всі багатства, сховані на морському дні, тому що тільки вона здатна подарувати йому надію повернути любов дівчини: «Ищи, кто хочет, в море / Богатых янтарей... / А мне моё колечко / С надеждою моей» ${ }^{8}$.

У «Пісні», написаній у 1820 р., яка $є$ вільним перекладом вірша Дж.Г. Байрона «Станси для музики» (1816), образ моря набуває абсолютно іншого значення. Автор розмірковує про передчасну старість душі та про в'ялість серця. Море в цьому випадку є не частиною могутньої природи, як у попередньому вірші: тут представлено море життя, немилосердне до зневіреної людини, яка втратила щастя: «Наше счастие разбитое / Видим мы игрушкой волн, /

5 Жуковский В.А. Избранное / сост., вступ. ст. и прим. И.М. Семененко ; ил. А.В. Озеревской. Москва : Правда, 1986. С. 72.

6 Там само.

7 Там само.

${ }^{8}$ Там само. С. 73. 
И в далёкий мрак сердитое / Море мчит наш бедный чёлн...» ${ }^{9}$. Хвилі уособлюють неправду, наклеп і лихослів'я, якими сповнений світ людей, а човен - самотню людину, вигнану з цього світу. Таким чином, море $\epsilon$ тут своєрідною глибинною метафорою та являє собою «морський» код «неморського» повідомлення. Відкинутий блукач не може знайти свого місця в житті й ніщо не може врятувати його під час бурі: «Стрелки нет путеводительной, / Иль вотще её магнит / В бурю к пристани спасительной / Чёлн беспарусный манит» ${ }^{10}$.

Найяскравішим зразком мариністичної лірики В.А. Жуковського $\epsilon$ елегія «Море» (1822), у якій йому 3 неймовірною красою вдалося відобразити свої мрійливі та задумливі переживання. О.С. Пушкін у листі до В'яземського (близько 25 січня 1829 р.) виділив з альманаху «Північні квіти» саме цей вірш: «Читал цветы? Каково море Жуковского...» ${ }^{11}$.

Поет уособлює море, зображуючи його живою істотою, яка все відчуває та мислить: «Безмолвное море, лазурное море, / Стою очарован над бездной твоей. / Ты живо; ты дышишь; смятенной любовью, / Тревожною думой наполнено ты» ${ }^{12}$. Він звертається до моря з питаннями, які пов'язують картини природи з філософськими роздумами про одвічні таїни буття: «Что движет твоё необъятное лоно? / Чем дышит твоя напряжённая грудь?» ${ }^{13}$.

Елегія написана чотиристопним амфібрахієм і білим віршем, які допомогли В.А. Жуковському передати безмовність моря, рух хвиль, коливання морської поверхні. Море зображено в його спокійному стані, під час бурі та після неї. Усі три картини чудові, тому що пов'язані з настроєм, світом емоцій і почуттів людини.

У спокійній морській гладі відбиваються й золоті хмари, і блиск зірок, і чиста лазур неба. Море постає перед читачем пристрасною стихією, яка приховує під покровом таємничої безмовності свою любов до неба, до якого вона тягнеться із «земныя неволи», щоб знайти омріяну свободу. Тільки там, у височині, усе $\epsilon$ прекрасним і вічним: «Таинственной, сладостной полное жизни, / Ты чисто в присутствии чистом его: / Ты льёшься его светозарной лазурью, / Вечерним

9 Жуковский В.А. Избранные произведения: стихотворения, баллады, повесть в стихах: для ст. школ. возраста / сост., предисл., примеч. и словарь В.И. Коровина ; худож. С.Г. Якутович. Киев : Веселка, 1984. С. 83.

${ }^{10}$ Там само.

11 Там само. С. 211.

12 Жуковский В.А. Избранное / сост., вступ. ст. и прим. И.М. Семененко ; ил. А.В. Озеревской. Москва : Правда, 1986. С. 105.

${ }^{13}$ Там само. С. 106. 
и утренним светом горишь, / Ласкаешь его облака золотые / И радостно блещешь звездами его ${ }^{14}$.

Під час бурі, коли «сбираются тёмные тучи», небезпека розлуки змушує морську стихію збунтуватися та вимагати повернення небес. Борючись за свій ідеал, море б'ється, виє та здіймає хвилі, шум яких чудово переданий В.А. Жуковським за допомогою алітерації: «Ты бьёшься, ты воешь, ты волны подъемлешь, / Ты рвёшь и терзаешь враждебную мглу...» 15 . Коли буря закінчується, «полное прошлой тревоги своей» море ще довго здіймає «испуганны волны», потім воно заспокоюється, але цей спокій оманливий: море не залишає страх знову втратити «сладостный блеск возвращённых небес»: «Обманчив твоей неподвижности вид: / Ты в бездне покойной скрываешь смятенье, / Ты, небом любуясь, дрожишь за него» ${ }^{16}$.

У 1831 р. В.А. Жуковський знову звертається до образу моря, перекладаючи вірш німецького поета-романтика Людвіга Уланда «Замок на березі моря» (1805). Вірш являє собою розмову двох товаришів, які в різний час відвідали мешканців замка на березі моря. Один із них повний захоплення морським пейзажем і враженнями від подорожі, тоді як інший задумливий і сумний: «Ты видел ли замок на бреге морском? / Играют, сияют над ним облака; / Лазурное море прекрасно кругом». / «Я замок тот видел на бреге морском; / Сияла над ним одиноко луна; / Над морем клубился холодный туман» ${ }^{17}$.

Стан моря алегорично передає душевний стан ліричних героїв, які переносять на його опис власні переживання. Один із товаришів порівнює веселий спів юної царівни 3 плескотом морської хвилі, а інший згадує лише «печальную песнь», що повідомляла про іiі загибель: «Шумели ль, плескали ль морские валы? / С их шумом, с их плеском сливался ли глас / Весёлого пенья, торжественных струн?» / «Был ветер спокоен; молчала волна; / Мне слышалась в замке печальная песнь; / Я плакал от жалобных звуков её» ${ }^{18}$. У щасливі дні море неначе радіє разом із мешканцями замка, а у дні скорботи мовчання його хвиль передає глибокий смуток.

У 1832 р. Жуковський перекладає баладу Л. Уланда «Морська подорож короля Карла» (1815), називаючи іï «Плавання Карла Великого». Балада побудована за мотивами середньовічних французьких легенд 3 уведенням низки персонажів із французького середньовічного

\footnotetext{
14 Там само.

15 Там само.

16 Там само.

${ }^{17}$ Там само. С. 113.

${ }^{18}$ там само. С. 113-114.
} 
героїчного епосу - «Пісні про Роланда» (XI ст.). Акцент у ній робиться не на пригодах Карла та його супутників під час поїздки до святих місць, а на стані моря, яке намагається перешкодити цій поїздці.

3 перших рядків балади цілком очевидною $є$ ворожість моря до мандрівників: «Раз Карл Великий морем плыл, / И с ним двенадцать пэров плыло, / Их путь в святую землю был; / Но море злилося и выло» ${ }^{19}$. Відважний Роланд зізнається у тому, що сила та відвага, які вірно служать йому на землі, можуть підвести його під час морської битви: «Тогда Роланд сказал друзьям: / «Деруся я на суше смело; / Но в злую бурю по волнам / Хлестать мечом плохое дело» ${ }^{20}$. Пери налякані «ревущими волнами», що заглушають звуки струн і здатні поглинути не тільки їхні мечі, а і їх самих. Тюрпін-святитель у розпачі звертається до небес і прохає бога вгамувати море, що розбурхалося: «Явись и в пристань по волнам / Нас, грешных, проведи, Спаситель!» ${ }^{21}$. Мотив морського дна виникає разом із думками про можливу смерть: «Беда! сказал Риоль седой, - / Но если море не уймётся, / То мне на старости в сырой / Постели нынче спать придётся» ${ }^{22}$. У повному безсиллі перед мешканцями моря зізнається й Ламберт, який уважає за краще уникнути боротьби з ними: «Ламберт прибавил: «Что за честь / С морскими чудами сражаться? / Гораздо лучше рыбу есть, / Чем рыбе на обед достаться» ${ }^{23}$. Один тільки Карл зберігає спокій під час шторму. Небо чує молитви Тюрпіна, та буря припиняється. Перед королем виникає рятівний берег життя, знаходження якого $\epsilon$ надзвичайно важливим серед моря, яке загрожує всілякими небезпеками: «А Карл молчал: он у руля / Сидел и правил. Вдруг явилась / Святая вдалеке земля, / Блеснуло солнце, буря скрылась» ${ }^{24}$.

В.А. Жуковського справедливо називають геніальним перекладачем. Його переклади не тільки знайомили російського читача зі світовою літературою, а й вростали в російський грунт, активно включаючись у літературний процес. Серед проаналізованих віршів тільки «Море» $\epsilon$ оригінальним віршем В.А. Жуковського, усі інші - вільним перекладом відомих творів зарубіжних поетів-романтиків. Варто зазначити, що під час перекладу їхніх віршів поет дуже часто звертався до образу моря, надаючи йому кожного разу абсолютно нового звучання. Вінцем діяльності В.А. Жуковського як перекладача давнього епосу є переклад гомерівської «Одіссеї» (1842-1849), у якій його привабили не тільки

\footnotetext{
${ }^{19}$ Там само. С. 248.

${ }^{20}$ Там само.

21 там само. С. 249.

${ }^{22}$ Там само.

${ }^{23}$ Там само. С. 249-250.

${ }^{24}$ Там само. С. 250.
} 
ідейний зміст і велика увага до емоційної сфери життя, а й образ величного моря, населеного чарівними істотами, яке протягом довгих двадцяти років було вірним супутником царя острова Ітака.

Як бачимо, у проаналізованих віршах В.А. Жуковського, присвячених морській темі, представлено «реальне» море, яке є частиною об'єктивної дійсності, і тільки в «Пісні» (1820) представлено море життя, немилосердне до самотнього блукача, вигнаного зі світу людей. Найбільш розповсюдженими мотивами «морського» комплексу в ліриці В.А. Жуковського є море, хвилі та берег.

\section{2. Аналіз «морського комплексу»}

\section{в романтичній ліриці М.Ю. Лермонтова}

М.Ю. Лермонтов - гідний сучасник О.С. Пушкіна, чия творчість знаменує собою вершину російського романтизму. Його ранні романтичні вірші пройняті розчаруванням у дійсності, характерним для післягрудневих умонастроїв, скептицизмом, прагненням до ідеалу вільної та бентежної особистості. Це пояснюється тим, що поет говорить у віршах про свій час похмуру й тяжку епоху $30-\mathrm{x}$ рp. XIX ст.

Вихідним і визначальним у романтичній ліриці М.Ю. Лермонтова є мотив неприйняття навколишнього світу, з яким не міг примиритися бентежний дух поета. Своїми віршами поет закликав сучасників до дії, до боротьби в ім'я власної свободи та свободи наступних поколінь. Російський письменник і філософ В.В. Розанов бачив його місію в такому: «Мне как-то он представляется духовным вождём народа» ${ }^{25}$.

Тиранам і рабам у М.Ю. Лермонтова протистоїть володар гострого розуму та живого почуття - любові до свободи. Прагнення до свободи породжує бажання активно боротися за неї. Тому долею такої особистості стає самотність у «стране рабов, стране господ». Романтичний герой приречений бути вічним блукачем, вигнанцем, в'язнем.

Одним зі способів знаходження довгоочікуваної свободи $є$ втеча у світ природи. Уже в ранніх романтичних віршах М.Ю. Лермонтова виникає образ моря, дорогого йому із самого дитинства, яке захоплює його своєю величчю та непокірністю, адже таким $є$ і сам бентежний дух поета. Юний М.А. Лермонтов порівнює себе 3 «певцом моря» Дж.Г. Байроном, підкреслюючи свою любов до моря, і мріє бути 3 ним людиною однакової долі: «Как он, ищу забвенья и свободы, / Как он, в ребячестве пылал уж я душой, / Любил закат в горах, пенящиеся воды, / И бурь земных и бурь небесных вой» ${ }^{26}$.

${ }^{25}$ Иванов Г.В., Калюжная Л.С. Сто великих писателей. Москва : Вече, 2005. С. 258.

26 Архипов В.А. М.Ю. Лермонтов. Поэзия познания и действия. Москва Московский рабочий, 1965. С. 130. 
Образ моря як вільної та незалежної стихії пов'язується М.Ю. Лермонтовим також з іменем іншого кумира його покоління Наполеона, i п'ятнадцятирічний юнак присвячує йому повні захоплення рядки: «Где бьёт волна о брег высокой, / Где дикий памятник небрежно положён, / В сырой земле и в яме неглубокой - / Там спит герой, друзья! - Наполеон!.. / Вещают так и камень одинокой, / И дуб возвышенный, и волн прибрежных стон!..» ${ }^{27}$.

Мотиви хвиль, берега, а також неба з'являються й у написаному роком пізніше однойменному вірші «Наполеон», який має підзаголовок «Дума»: «чья тень, чей образ там, / На берегу, склонивши взор к волнам, / Стоит вблизи нагбенного креста? / Пред ним лепечут волны и бегут, / И вновь приходят, и о скалы бьют; / Как лёгкие ветрилы, облака / Над морем носятся издалека» ${ }^{28}$.

У вірші «Св. Олена» (1831) поет знову звертається до образу свого кумира, підкреслюючи його спорідненість із непереможною морською стихією: «Сын моря, средь морей твоя могила! / Вот мщение за муки стольких дней! / Порочная страна не заслужила, / Чтобы великий жизнь окончил в ней» ${ }^{29}$.

Наслідуючи Ф. Шиллера та В.А. Жуковського, який перекладав його вірші, М.Ю. Лермонтов звертається до жанру романтичної балади й у 1829 р. пише «Баладу», у якій говорить про спорідненість морської стихії та жінки. У вірші наявні три рівноправні герої: «красавица-дева», море та юнак. Дівчина прохає юнака дістати 3 «пучины» намисто, щоб довести свою любов. Він кидається за намистом у «пенную» безодню: «Достань ожерелье, спустися на дно; / Сегодня в пучину упало оно! / Ты этим докажешь свою мне любовь!» / Вскипела лихая у юноши кровь, / И ум его обнял невольный недуг, / Он в пенную бездну кидается вдруг» ${ }^{30}$. Із вірша зрозуміло, що «красавицу-деву» зовсім не лякають ті небезпеки, які чекають у пучині на «милого друга», тоді як для юнака море - ворожа стихія. Воно $є$ символом кохання та пристрасті, що поглинає парубка. Намагаючись знову довести свою любов, він стрибає в море, «чтоб найти иль коралл, иль конец». Морське дно є символом смерті, оскільки спроба побороти морську стихію призводить до загибелі юнака: «Из бездны перловые брызги

27 Лермонтов М.Ю. Избранные произведения : в 2 т. / вступ. ст. П.Г. Антокольского ; сост. Б.М. Эйхенбаум ; примеч. Э.Э. Найдича. 2-е изд. Москва ; Ленинград : Советский писатель, 1964. Т. 1 : 1828-1834. С. 76.

${ }^{28}$ Там само. С. 107.

${ }^{29}$ Там само. С. 197.

${ }^{30}$ Там само. С. 87-88. 
летят, / И волны теснятся, и мчатся назад, / И снова приходят, и о берег бьют, / Но милого друга они не несут» ${ }^{31}$.

У 1830 р. М.Ю. Лермонтов пише близькі один до одного за ідейним змістом вірші - «Гроза» та «Гроза шумить в морях з кінця в кінець...». Перший починається описом розбурханої морської стихії, якій відповідає не менш грізне небо, покрите хмарами: «Ревёт гроза, дымятся тучи / Над тёмной бездною морской, / И хлещут пеною кипучей, / Толпятся, волны меж собой» ${ }^{32}$.

Незважаючи на «стихий тревожный рой», герой вірша залишається «недвижим», «надземные силы» не можуть його налякати, вони ніщо порівняно 3 неправдою, наклепом i «ядом сердечным», якими сповнений світ людей. Саме тому розбурхані стихії не спроможні викликати в нього нічого, крім байдужості: «О нет! - летай, огонь воздушный, / Свистите, ветры, над главой; / Я здесь, холодный, равнодушный, / И трепет незнаком со мной» ${ }^{33}$.

Герой другого вказаного вірша також зберігає повний спокій під час бурі, оскільки морська стихія є невід'ємною частиною його життя, до якої він звик за довгі роки: «Гроза шумит в морях с конца в конец. / Корабль летит по воле бурных вод, / Один на нём спокоен лишь пловец, / Чело печать глубоких дум несёт» ${ }^{34}$.

Плавець, як і герой вірша «Гроза», упевнений, що світ людей набагато небезпечніший, ніж морський шторм, а тому ніщо не здатне зворушити його мужнє серце: «Конечно, он живал между людей / И знает жизнь от сердца своего; / Крик ужаса, моленья, скрып снастей / Не трогают молчания его» ${ }^{35}$.

Розчаруванням у людях пройнятий i вірш «Хвилі та люди», написаний поетом у шістнадцятирічному віці, у якому він доходить невтішного висновку, що душі людей, які думають тільки про себе, набагато холодніші за хвилі: «Волнам их неволя и холод дороже / Знойных полудня лучей; / Люди хотят иметь души... и что же? - / Души в них волн холодней!» ${ }^{36}$.

Море перед грозою зображено у вірші «Човник» (1830), який починається описом бурі, що швидко насувається: «Воет ветр и свистит пред недальной грозой; / По морю, на тёмный восток, / Озаряемый молньей, кидаем волной, / Несётся неверный челнок» ${ }^{37}$.

\footnotetext{
${ }^{31}$ Там само. С. 88.

${ }^{32}$ Там само. С. 105.

${ }^{33}$ Там само.

${ }^{34}$ Там само.

${ }^{35}$ Там само. С. 106.

36 Там само. С. 158.

${ }^{37}$ Там само. С. 112.
} 
У човнику сидять два гребці, а біля їхніх ніг лежить під білою полотниною тяжко поранена людина. Незважаючи на рану «близ сердца», вона «смерть равнодушнее спутников ждёт». Варто зазначити, що погляд умираючої людини, яка знесла стільки страждань, порівнюється з хмарами та хвилями напередодні бурі: «Взор мрачен и дик, как сражения дым, / Как тучи на небе иль волны под ним» ${ }^{38}$.

Юний поет підводить підсумок своїм ідейним пошукам у вірші «1831-го червня 11 дня», який можна назвати «выдающимся произведением русской медитативной лирики» ${ }^{39}$. Морський пейзаж надає нового сенсу та забарвлення настрою ліричного героя, який упевнений у тому, що «жизнь скучна, когда боренья нет». Епоха сковує героя в його бажаннях, ставлячи їм межі та перешкоди, але його бентежний дух не знає спокою і завжди готовий до дії, що передано за допомогою опису такої ж непокірної морської хвилі: «Когда, гонима бурей роковой, / Шипит и мчится с пеною своей, / Она всё помнит тот залив родной, / Где пенилась в приютах камышей, / И, может быть, она опять придёт / В другой залив, но там уж не найдёт / Себе покоя: кто в морях блуждал, / Тот не заснёт в тени прибрежных скал» ${ }^{40}$.

Герой, приречений на трагічну загибель, говорить про те, що на нього чекає могила «на диком берегу ревущих вод», знову підкреслюючи спорідненість свого духу з морською стихією. Море побачить перед собою і молодий чужоземець, який прийде до цієї могили: «И печаль / Его встревожит, он посмотрит вдаль, / Увидит облака с лазурью волн, / И белый парус, и бегучий чёлн» ${ }^{41}$.

Цілком очевидно, що цьому «философскому монологу» близьким за ідеєю та засобами художнього вираження $\epsilon$ «Парус», написаний у серпні 1832 p. на березі Балтійського моря, який справедливо вважається шедевром юнацької лірики М.Ю. Лермонтова. Жодний ліричний твір поета не аналізувався так часто й докладно, як 12-рядковий «Парус», який можна назвати «эпиграфом ко всей лермонтовской лирике» ${ }^{42}$. Різноманітні тлумачення вірша відображено в дослідженнях М.М. Шанського, В.І. Коровіна, І.Н. Розанова, С.В. Ломінадзе, М.М. Гіршмана, В.М. Марковича.

${ }^{38}$ там само. С. 113.

39 Архипов В.А. М.Ю. Лермонтов. Поэзия познания и действия. Москва : Московский рабочий, 1965. С. 142.

40 Лермонтов М.Ю. Избранные произведения : в 2 т. / вступ. ст. П.Г. Антокольского ; сост. Б.М. Эйхенбаум ; примеч. Э.Э. Найдича. 2-е изд. Москва ; Ленинград : Советский писатель, 1964. Т. 1: 1828-1834. С. 191.

${ }^{41}$ Там само. С. 192.

42 Шанский Н.М. Лингвистический анализ художественного текста : учебное пособ. для студ. пед. инст. 2-е изд., дораб. Ленинград : Просвещение, 1990. С. 339. 
Перший рядок - «Белеет парус одинокий» - запозичений з анонімно виданої в 1828 р. в Москві поеми російського письменника-романтика, офіцера-декабриста О.О. Бестужева (Марлінського) «Андрій, князь Переяславський» (розділ I, частина 15, строфа 19): «Белеет парус одинокий, / Как лебединое крыло, / И грустен путник ясноокий, / У ног колчан, в руке весло» ${ }^{43}$.

Але у вірші М.Ю. Лермонтова йдеться не про човник: парус уособлює самотнього блукача, одвічного мандрівника, який не може примиритися 3 оточуючою його дійсністю. Уже в першій строфі ми стикаємося 3 мотивом самотності: «Белеет парус одинокий / В тумане моря голубом!..» ${ }^{44}$.

Ліричний герой $є$ самотнім передусім у морі життя й не знаходить собі місця ні «в стране далёкой», ні «в краю родном». Бурхлива морська стихія не лякає його, оскільки позбавитися самотності він збирається в активній діяльності. Він рухається назустріч невідомому та біжить від життя, що йому наскучило, не намагаючись знайти щастя, тому що його немає ні в умиротворенні та спокої, коли море виявиться лагідним і безтурботним, ні в бурі: «Увы, - он счастия не ищет / И не от счастия бежит!» ${ }^{45}$.

Ключовим поняттям вірша $€$ зазначення бентежності героя. Гармонія та спокій не для нього: «А он, мятежный, просит бури, / Как будто в бурях есть покой!» ${ }^{46}$.

Самотній парус, що мандрує морем, має мужність кинути виклик долі, виражаючи свій протест проти ситого міщанського життя, у чому бачимо втілення одного із найважливіших постулатів романтизму.

Бентежним духом поета пройнятий і вірш «Бажання» (1832), у якому підкреслюється готовність героя до ризику, бажання змагатися зі стихією, якою б страшною вона не була: «Дайте мне челнок дощатый / С полусгнившею скамьёй, / Парус серый и косматый, / Ознакомленный с грозой» ${ }^{47}$.

У вірші знову з'являються мотиви грози та паруса, традиційні для мариністичної лірики поета. Боротьба зі стихією дає герою впевненість у своїх силах. Чим грізнішим і непередбаченішим буде море, тим більше загартується його дух: «Я тогда пущуся в море, / Беззаботен

${ }^{43}$ Андреев-Кривич С.А. Всеведенье поэта. Москва : Советская Россия, 1973. С. 220.

44 Лермонтов М.Ю. Избранные произведения : в 2 т. / вступ. ст. П.Г. Антокольского ; сост. Б.М. Эйхенбаум ; примеч. Э.Э. Найдича. 2-е изд. Москва ; Ленинград : Советский писатель, 1964. Т. 1 : 1828-1834. С. 263.

${ }^{45}$ Там само.

${ }^{46}$ Там само.

47 Там само. С. 255. 
и один, / Разгуляюсь на просторе / И потешусь в буйном споре / С дикой прихотью пучин» ${ }^{48}$.

«Буйный спор с дикой прихотью пучин» дає герою радість i насолоду свободою. Тільки в ньому бентежний дух поета здатний задовольнитися.

Цікавим $\epsilon$ той факт, що в словнику М.Ю. Лермонтова слово «буря» зустрічається 131 раз, притому в різних значеннях, «бурный» - 21, «мятежный» разом із «мятежно» - 43, а «счастие» - 301 раз. Буря найчастіше заміняє щастя, і вибір робиться свідомо ${ }^{49}$.

Найяскравішим твором мариністичної лірики М.Ю. Лермонтова вважається поема «Моряк», написана в 1832 р. онєгінською строфою. Уривок із неї, який дійшов до наших днів, можна назвати гімном морським хвилям. Епіграфом до твору слугують слова 3 поеми «Корсар» Дж.Г. Байрона. Поема М.Ю. Лермонтова написана від імені ліричного героя, моряка, уже в перших іiі рядках очевидним є його захоплення морською стихією: «В семье безвестной я родился / Под небом северной страны, / И рано, рано приучился / Смирять усилия волны» ${ }^{50}$.

Море не $\epsilon$ ні ворожою щодо моряка стихією, яким воно було для юнака у «Баладі», ні суперником у боротьбі, яким воно представлено у вірші «Бажання». Море дарує йому почуття могутності на наповнює його душу щастям: «Как я могущ себе казался, / Когда на воздухе качался, / Держась упругою рукой / За парус иль канат сырой; / Я был меж небом и волнами, / На облака и вниз глядел, / И не смущался, не робел, / И, всё окинувши очами, / Я мчался выше - о! тогда / Я счастлив был, да, счастлив, да!»"

Моряк називає хвилі своӥми друзями та говорить, що «понимал их разговор». Він порівнює їх із морськими богами та ставиться до них як до живих істот: «И каждый вечер предо мной / Они в одежде парчевой, / Как люди, гордые являлись; / Обворожён, я начал им / Молиться, как богам морским / «...» И в море каждая волна / Была душой одарена» ${ }^{52}$.

Далі йде порівняння «гордой волны» 3 «девой молодой», причому краса саме хвилі уявляється моряку вічною: «Но вянут девы в тишине, / А волны, волны, всё одне» ${ }^{53}$.

${ }^{48}$ Там само.

${ }^{49}$ Кормилов С.И. Поэзия М. Ю. Лермонтова: в помощь преподавателям, старшеклассникам и абитуриентам. Москва : Издательство МГУ, 1997. С. 44-45.

50 Лермонтов М.Ю. Избранные произведения : в 2 т. / вступ. ст. П.Г. Антокольского ; сост. Б.М. Эйхенбаум ; примеч. Э.Э. Найдича. 2-е изд. Москва ; Ленинград : Советский писатель, 1964. Т. 1: 1828-1834. С. 400.

${ }^{51}$ Там само. С. 401.

52 Там само. С. 401-402.

53 Там само. С. 402. 
Хвилі є втіленням свободи, і саме тому вони так дорогі серцю моряка: «Я обожатель их свободы! - / Как я в душе любил всегда / Их бесконечные походы / Бог весть откуда и куда» ${ }^{54}$.

Моряк вірить у могутність близької йому морської стихії й у тяжку хвилину кличе на допомогу «творца», благаючи його залишити за нею перемогу й тим самим зберегти йому життя на кораблі - його «родине»: «Сколько раз / На корабле, в опасный час, / Когда летала смерть над нами, / Я в ужасе творца молил, / Чтоб океан мой победил!» ${ }^{55}$.

У 1841 р. М.Ю. Лермонтовим написана «Морська царівна», деякі деталі якої нагадують вірш «Яниш королевич» із циклу «Пісні західних слов'ян» О.С. Пушкіна. У цьому вірші, як і в «Баладі», очевидною $\epsilon$ спорідненість морської стихії та жінки. «Царская дочь» намагається заманити царевича в море, обіцяючи йому всілякі втіхи. Побоюючись явно ворожої йому стихії, юнак виносить свою «добычу» на берег, незважаючи на ії благання цього не робити: «Мыслит царевич: «Добро же! постой!» / За косу ловко схватил он рукой. / Держит, рука боевая сильна: / Плачет и молит и бьётся она» ${ }^{56}$.

На березі царевич кличе друзів, щоб показати їм надзвичайну красу своєї полонянки, але вона помирає, оскільки не може існувати поза морем: «Вот оглянулся царевич назад: / Ахнул! померк торжествующий взгляд. / Видит, лежит на песке золотом / Чудо морское с зелёным хвостом / «...» Пена струями сбегает с чела, / Очи одела смертельная мгла» ${ }^{57}$.

Варто звернути увагу на той факт, що русалка помирає саме в той момент, коли морська піна збігла з іі обличчя, тобто тоді, коли втрачений останній зв'язок із рідним їй морем.

Вірш закінчується явною погрозою: «Едет царевич задумчиво прочь. / Будет он помнить про царскую дочь!» ${ }^{58}$.

Ця погроза повністю закономірна, оскільки людина зробила замах на стихію, що їй протистоїть, а тому покарання буде неминучим.

На основі аналізу віршів М.Ю. Лермонтова, об'єднаних морською темою, можна зробити висновок, що в них представлено «реальне» море, за винятком вірша «Парус», у якому парус «заміщає» образ самотнього мандрівника, котрий блукає морем життя. Найрозповсюдженішими мотивами «морського» комплексу в ліриці М.Ю. Лермонтова є, окрім моря, хвилі та берег. Рідше виникають образи дна - символу смерті -

${ }^{54}$ Там само.

55 Там само. С. 403.

56 Лермонтов М.Ю. Стихотворения; Поэмы; Маскарад; Герой нашего времени.

Москва : Художественная литература, 1984. С. 143.

57 Там само.

${ }^{58}$ Там само. С. 144. 
і неба - стихії, що протистоїть морю та викликає думки про безсмертя. Хмари часто протиставляються хвилям 3 метою створення контрасту.

\section{ВИСНОВКИ}

У проаналізованих віршах В.А. Жуковського, присвячених морській темі, представлено «реальне» море, яке $\epsilon$ частиною об'єктивної дійсності, і тільки в «Пісні» (1820) представлено море життя, немилосердне до самотнього блукача, вигнаного зі світу людей. Найбільш розповсюдженими мотивами «морського» комплексу в ліриці В.А. Жуковського $є$ море, хвилі та берег. У «Пісні» (1816) море $\epsilon$ ворожим щодо ліричного героя, воно сильніше земної та повітряної стихії, а мотив морського дна, що поглинуло каблучку, символізує загублені кохання та земне щастя. У «Пісні» (1820) морські хвилі уособлюють неправду, наклеп, лихослів'я, якими сповнений світ людей. Отже, море виступає в цьому вірші глибинною метафорою. У найяскравішому зразку мариністичної лірики В.А. Жуковського елегії «Море» - особливу роль відведено мотиву неба, яке символізує свободу та вічність. Море, як жива істота, милується ясним небом i боїться його втратити. У «Замку на березі моря» опис моря ліричними героями передає їхній душевний стан і переживання під час відвідування замка. Найповніше реалізується «морський» комплекс у «Плаванні Карла Великого», оскільки у вірші наявні всі його мотиви. Море є ворожим щодо Карла та його супутників: воно намагається перешкодити їхній поїздці до святих місць. Мотив морського дна символізує ймовірну смерть. Почувши молитви мандрівників, небо утихомирює розбурхане море та проводжає їх хвилями до рятівного берега життя.

Щодо проаналізованих віршів М.Ю. Лермонтова, об'єднаних морською темою, варто зазначити, що в них представлено «реальне» море, за винятком вірша «Парус», де парус «заміщає» образ самотнього мандрівника, який блукає морем життя. Найрозповсюдженішими мотивами «морського» комплексу в ліриці М.Ю. Лермонтова $є$, окрім моря, хвилі та берег. Рідше виникають образи морського дна - символу смерті - і неба - стихії, що протистоїть морю та викликає думки про безсмертя. Хмари часто протиставляються хвилям з метою створення контрасту. Проаналізовані вірші можуть бути згруповані відповідно до їх ідейного змісту. У двох однойменних віршах «Наполеон» і у вірші «Св. Олена» море співзвучне духові великого кумира покоління та $\epsilon$ уособленням свободи й непокірності. Вірші «Гроза», «Гроза шумить в морях з кінця в кінець...» $\mathrm{i}$ «Хвилі та люди» пройняті розчаруванням у людях, душі яких, на думку поета, набагато холодніші за морські хвилі. Морська буря, що насувається, зображена також і у вірші «Човник», у якому, окрім розчарування, наявний мотив смерті. 
У «Баладі» та «Морській царівні» йдеться про спорідненість морської стихії та жінки. Для людини, яка зробила замах на багатства моря або його мешканців, стихія є ворожою. Бентежним духом поета пройняті вірші «1831-го червня 11 дня», «Парус» і «Бажання», в останньому 3 яких очевидним є бажання героя боротися з морською стихією, яка $\epsilon$ його суперником. Море в поемі «Моряк», навпаки, є другом героя, здатним подарувати йому почуття могутності й свободи.

\section{АНОТАЦІЯ}

Дослідження присвячено аналізу «морського» комплексу в ліриці двох видатних представників російського романтизму В.А. Жуковського та М.Ю. Лермонтова. Визначено фактори, які зумовили виникнення мариністичної літератури як художнього феномена російського романтизму. Згідно з визначенням «поетичного» комплексу моря, запропонованим В.М. Топоровим, указані його складники (море, хвилі, берег, морське дно та небо). Виділено дві романтичні версії «морського комплексу» - «реальне» море та море, що «заміщає» собою інші образи. Показана роль образу моря у творах указаних поетів, розкрита його багатозначна символіка. Установлено, що найрозповсюдженішими мотивами «морського комплексу»в в̈хній романтичній ліриці є море, хвилі та берег.

\section{ЛITЕРАТУРА}

1. Андреев-Кривич С.А. Всеведенье поэта. Москва : Советская Россия, 1973. 253 с.: ил.

2. Архипов В.А. М.Ю. Лермонтов. Поэзия познания и действия. Москва : Московский рабочий, 1965. 472 с.

3. Жуковский В.А. Избранное / сост., вступ. ст. и прим. И.М. Семененко ; ил. А.В. Озеревской. Москва : Правда, 1986. 560 с.: ил.

4. Жуковский В.А. Избранные произведения: стихотворения, баллады, повесть в стихах: для ст. школ. возраста / сост., предисл., примеч. и словарь В.И. Коровина ; художн. С.Г. Якутович. Киев: Веселка, 1984. 236 с.: ил.

5. Иванов Г.В., Калюжная Л.С. Сто великих писателей. Москва : Вече, 2005. $592 \mathrm{c.}$

6. Кормилов С.И. Поэзия М.Ю. Лермонтова: в помощь преподавателям, старшеклассникам и абитуриентам. Москва : Издательство МГУ, 1997. $128 \mathrm{c.}$

7. Лермонтов М.Ю. Избранные произведения : в 2 т. / вступ. ст. П.Г. Антокольского ; сост. Б.М. Эйхенбаум ; примеч. Э.Э. Найдича. 2-е изд. Москва ; Ленинград : Советский писатель, 1964. Т. 1: 1828$1834.714 \mathrm{c}$. 
8. Лермонтов М.Ю. Стихотворения; Поэмы; Маскарад; Герой нашего времени. Москва : Художественная литература, 1984. 493 с.

9. Ніколенко О.М. Романтизм у поезії. Г. Гейне, Дж.Г. Байрон, А. Міцкевич, Г. Лонгфелло : посібник для вчителя. Харків : Ранок, 2003. 176 с.: іл.

10. Топоров В.Н. Миф. Ритуал. Символ. Образ: исследования в области мифопоэтического: избранное. Москва : Издательская группа «Прогресс»-«Культура», 1995. 624 с.

11. Шанский H.M. Лингвистический анализ художественного текста: учебное пособие для студ. пед. инст. 2-е изд., дораб. Ленинград : Просвещение, 1990. 415 с.

\section{Information about the author:}

Karpina O. S.,

Candidate of Philological Sciences, Associate Professor at the Department of World Literature Horlivka Institute for Foreign Languages of the Donbas State Pedagogical University 24, Vasyl Pershyn str., Bakhmut, Donetsk region, 84511, Ukraine 